\title{
Service provider boundaries in competitive markets: The case of the logistics industry
}

The study empirically investigates service provider firms' attempts to move to higher valueadded market segments in competitive and fragmented markets; using logistics services as a context. Novelty is added by taking the provider not the customer or outsourcing actor perspective, common to current third-party logistics perspectives. Data were collected in the form of semi-structured interviews with management at various provider firms. The interview guide was based on theoretical constructs regarding tangible and intangible capabilities (RBV) as well as constructs related to governance and integration (TCE). Unlike customer focused studies, this study is able to identify what distinguishes the rare successful boundary crossing attempts that lead to a more profitable market position. The key finding which contradicts studies based on the customer/outsourcing actor perspective, is that a switch from a highly commoditized market position to a higher margin position is only possible, if relationships and network capabilities are leveraged, regardless of the assets and physical resources available to the firm. The presentation of service boundaries as both dynamic and fluid and the use of RBV are contributions, building on existing theory, illustrating why providers of commoditized services cannot escape from low-margin, competitive market positions simply by acquiring tangible assets.

Keywords: Service boundaries, service providers, logistics, competitive markets, Resource based view, Transaction cost economics 


\section{Introduction}

In economics core to highly competitive markets are two features; a large number of firms, and very low barriers to entry (Nilsson 2017). The large number of firms means that suppliers or providers are always price takers rather than price makers; they have to operate within narrow pricing bands set by the level of competitors. If providers try and operate outside that band, they will lose business to cheaper rivals. The low barriers to entry make the market attractive to potential new entrants, if for some reason prices and margins seem to be rising new entrants can easily enter the market undeterred by barriers such as high capital investment, regulatory hurdles or well respected brands. Take for example fast food outlets without a national brand, if a location proves highly profitable (say due to a high student footfall) competitors soon colocate, and pricing and product initiatives (say 2 for 1 Mondays) are easily copied and matched by competitors; any potential gains simply competed away. This predictability, coupled with low profitability accounts for a lack of academic interest in service providers operating in highly competitive markets. Yet a few service organisations will always find ways of going up market to a more attractive, more profitable, less competitive niche; markets are dynamic not bureaucratic. This is the topic this study addresses. How do some service businesses manage to transition to new, and better, market segments, whilst leaving the majority trapped in commoditised markets segments? The issue is made especially pressing by the association, in western economies, between increasing gross national wealth and the rise of services as a proportion of the economy.

Many concurrent drivers have contributed to creating service providers and new service provider roles, in new market segments. For example, servitisation has emerged as a strategy for a product led organisation to add value through additional services (e.g. maintenance, financing, repairs, upgrades, etc.) or less commonly for a service organisation to add a product (Lahy et al. 2017; Chiu et al. 2018). Offering effectively 'one stop shops' for customers combined with servitisation has led to new service markets where providers offer integrated solutions (Storbacka 2011; Roehrich and Caldwell 2012) or business solutions (Prior 2015). The idea of solutions is that through a unique mix of products and services a provider can offer a customer a customised solution at a higher margin than a standard offering. Therefore, extant literature offers an array of service provider led organisations, from the highly niche to the customised solution provider. Other drivers include the boom in outsourcing (Prahalad and Hamel 1990; Quinn and Hilmer 1994) and global outsourcing (Schoenherr 2010), customers' seeking modular interfaces with providers (Peters et al. 2018), the rise of Service led strategies 
(SLS) (Bustinza et al. 2015; Kowalkowski et al. 2017) and changes in the business environment for example the continuing expansion of B2C making supply chains longer. Longer supply chains have led to new service providers emerging, for example due to the level of internet based customer returns retailers have experienced (Chen and Chen 2016).

What these various drivers for service led strategies do not engage with though is the relative attractiveness of different service provider market segments. Service firms that are trapped in highly competitive markets will be under ceaseless margin and performance pressure (Bustinza et al. 2015; Kowalkowski et al. 2017; Zhang et al. 2017). Very few studies address this question: How can service provider firms in competitive industries re-position their offerings?

To address this question, the study adopts a qualitative approach, through interviews focused on the providers' themselves not their customers. Germany is identified as a highly competitive market for logistics services and is adopted in the research design as the context for the investigation. Theoretically (and in line with the previous work) the study utilizes a combination of transaction cost economics and the resource based view of the firm. The objective of the study is to contribute empirically to how some service firms are able to move out of commodified market positions.

The reminder of the paper is structured as follows, section 2 reviews the literature on logistics services including provider definitions, and Germany as a context for studying competition in logistics markets. It also covers the two theoretical positions that inform this study, transaction cost economics and the resource based view of the firm; producing an ex ante theoretical model. Chapter 3 discuss the research design and method, including examples of the interviewees and excerpts from the interview guide detailing the links to TCE and RBV. Chapter four presents the data, and chapter five provides the main analysis. Chapter six closes the paper with conclusions, managerial and research implications, limitations and an agenda for future research.

\section{Literature review}

\subsection{Logistics service provision context}

\subsubsection{Logistics service provision and competitive markets}

Markets for logistics service providers' appear one such market where both demand for widely varying levels of provider services and a continuing expansion in the opportunities to add value through services meet within a competitive market. The different levels of service that can be offered give potential for differentiation but barriers to entry are low; it is relatively easy to 
offer basic logistics services. Indeed, the bargaining power of basic logistics service providers' is reduced to a minimum due to the low entry-level requirements and the standardisation of logistics processes (Hertz and Alfredsson 2003; Chu and Wang 2012; Zhang et al. 2017). However third-party logistics (TPLs) firms do offer a high potential range of services and are differentiated based on offering forms of integration (Trentin 2011; Faber et al. 2018). However, 3PL's compete for the same customers and are forced to serve multiple customers at the same time (Mantin et al. 2014; Shi et al. 2016). In contrast to basic commodity like logistics service provision, is that of a solution or systems integrator role, typically called fourth-party logistics (4PL) providers (Win 2008; Huemer 2012). Very recent evidence suggests a new generation of venture capital funded logistics startups will at least intensify competition for standardised forwarders and 3PLs (Kurpjuweit et al. 2018).

\subsubsection{Defining Logistics services}

Until the 1970s, logistics operations were mainly conducted and organised in-house with a focus on storing and transporting finished products (Sheffi 1990; Bowersox et al. 2012). Logistics operations then acquire more management attention as the potential for cost savings in production and manufacturing was recognised; which ultimately initiated the development of an industry of third party logistics (TPL) or 3PL providers (Bowersox et al. 2012; Cui and Hertz 2011). The further integration of logistics activities in the 1990s and the linking of different functional areas, such as logistics, marketing and procurement led to development of enterprise resource planning (ERP) systems that finally allow manufacturers and producers to use service providers for the entire logistics function (Fabbe-Costes et al. 2008; Cui and Hertz 2011; Huemer 2012). Today, all operational and managerial processes and logistics activities can be outsourced to 3PL providers, who operate on behalf of their clients. The responsibilities and capabilities that these 3PL firms provide in today's business environments are multifaceted but range from traditional 'arm's-length' sourcing, such as organising and buying transportation and warehouse services, to managing more complex logistics processes (Yeung et al. 2012). 3PL providers can be divided into two main categories, 'those who own transportation assets and those who do not' (Sheffi 1990, p.34).

Additionally, various academics have attempted to categorise and classify third party logistics services as shown in Table 1 (Lieb 1992; Berglund et al. 1999; Skjøett-Larsen, 2000; Bask 2001; Marasco 2008; Selviaridis and Spring 2007; Cui and Hertz 2011). However, for the purposes of this study these definitions are flawed in that they are residual definitions; they define providers in relation to their customers; how the customer should use TPLs. For example, 
Halldórsson and Skjøett-Larsen (2004:192) are explict that they 'explain the opportunities and constraints that the companies face in moving from a non-strategic towards a strategic use (italics added for emphasis) of TPL. Skjøett-Larsen (2000) appears to add nuance, noting the long term nature of Scandinavian TPL relationships, but that study starts with long term TPL relationships. It does not address why some service providers are able to make this progression from short term commodified transactions to deeper relationships. Both Halldórsson and Skjøett-Larsen (2004:192) and Skjøett-Larsen (2000) propose typologies for the progress of customer-provider relationships. For Skjøett-Larsen (2000) there are five stages from a single transaction, to repeated transactions, to a partnership agreement, to a third party agreement culminating in an integrated logistics services agreement. The study goes on to address the importance of TCE and network theory, but not at the level of the TPL provider. Whilst Halldórsson and Skjøett-Larsen (2004) take great care to emphasise in the text that their typology should not be taken as a simple transition - from no relationship to fully integrated

Table 1. Definitions of SPL services from extent literature.

\begin{tabular}{|c|c|}
\hline Reference & Definition \\
\hline Ellram and Cooper (1990) & $\begin{array}{l}\text { Define third-party logistics providers as "outside parties who provide [shippers } \\
\text { with] functions not performed by the firm (p.1). }\end{array}$ \\
\hline Lieb (1992) & $\begin{array}{l}\text { The use of external companies to perform logistics functions that have } \\
\text { traditionally been performed within an organisation. The functions performed } \\
\text { by the third party can encompass the entire logistics process or selected activities } \\
\text { within the process (p.29). }\end{array}$ \\
\hline Bagchi and Virum (1996) & $\begin{array}{l}\text { A logistics alliance indicates a close and long-term relationship between a } \\
\text { customer and a provider encompassing the delivery of a wide array of logistics } \\
\text { needs. (p.95). }\end{array}$ \\
\hline Murphy and Poist (1998) & $\begin{array}{l}\text { A relationship between a shipper and third party, which, compared to basic } \\
\text { services has more customised offerings, encompasses a broader number of } \\
\text { service functions and is characterised by a longer term, more mutually beneficial } \\
\text { relationship (p.26). }\end{array}$ \\
\hline Berglund et al. (1999) & $\begin{array}{l}\text { Activities carried out by a logistics service provider on behalf of a shipper and } \\
\text { consisting of at least management and execution of transportation and } \\
\text { warehousing (p. 193) }\end{array}$ \\
\hline Skjøett-Larsen (2000) & $\begin{array}{l}\text { All logistics service relationships that include the last three categories of } \\
\text { Bowersox's scale, i.e. partnerships, third party agreements and integrated service } \\
\text { agreements (p.114). }\end{array}$ \\
\hline Bask (2001) & $\begin{array}{l}\text { Relationships between interfaces in the supply chains and third-party logistics } \\
\text { providers, where logistics services are offered, ranging from basic to }\end{array}$ \\
\hline
\end{tabular}


customised, in short or longer-term relationships, with the aim of effectiveness and efficiency (p.474).

Van Hoek and Chong A service provider that participates rather in supply chain co-ordination than (2001) operational services. It is highly information based and co-ordinates multiple asset-based players on behalf of its clients (p. 463).

Coyle et al. (2003) It involves an external organisation that performs all or part of a company's logistics functions (P.425).

relationship - that is how it is presented visually. In what they call a competence perspective, relationships progress in four stages from market exchanges, to customised logistics solutions, to joint logistics solutions finally to in-house logistics solutions, using three dimensions: competence, asset specificity and degree of integration. However again for that study is effectively a customer perspective and has no detail on how or which logistics service providers get chosen to undertake this journey with a customer.

Interestingly, these extant definitions of logistics services and associated logistics provider roles offer essentially static and discrete positions for services. More recently the range and variety of services offered has expanded greatly (Kayakutlu and Buyukozkan 2011) leading recent practitioner and industry studies (Kille and Schwemmer 2015; Langley and Capgemini 2015) to suggest that market conditions are changing rapidly and therefore the older, static service boundary positions between different provider firms may no longer be accurate.

\subsubsection{Germany as a context for studying provider boundaries}

This study attempts to examine the boundaries between service providers as both potentially dynamic, and overlapping, positions. The empirical study explores how service provider firms attempt to reposition their service offerings across service provision boundaries. Logistics service providers were chosen as a context, where there is a distinct demarcation between levels of service provision. This approach is in line with recent work that calls for broad definitions of third party logistics agreements as 'Intermediate forms are often difficult to classify (SkjøettLarsen, 2000: p115). Research design suggested logistics service providers based in Germany with their operations within Europe would fit the context required by the research question. The European logistics service market offers unique and challenging characteristics in terms of competition and density, mainly driven by the Eastern European liberalization in the 1980s. This European market has experienced constantly increasing demand mandating efficient logistic systems (Fabbe-Costes et al. 2008; Cui and Hertz 2011). The service offerings themselves have developed from standardised and commoditized transportation of full-truck- 
loads (FTL) to just-in-time deliveries and complex in-house logistics operations within production or assembly plants (Kille and Schwemmer 2015). Also, since the liberalisation of the European logistics market, Eastern European carrier and logistics firms have transformed the industry into a highly competitive and low-margin market (Cieslik and Michalek 2015). Prior to liberalisation, the logistics and transportation market was protected by licences and concessions. The deregulation of tariff-rate quotas for transportation services and further elimination of market barriers lead to a substantial drop in mileage and shipping prices within the European mainland. As a result, the industry fragmented and some logistics groups merged in order to offer more integrated services and industry specific operations. This trend of modifying and adjusting services in terms of scale and scope, challenges traditional service providers with their emphasis on undifferentiated (un-adapted) transportation and warehousing. These undifferentiated small and medium-sized provider firms struggle because they only provide commoditised services. Naturally some of these particularly medium-sized service providers in Germany are tempted to leap market boundaries to enter a less competitive, higher margin form of service provision. The study raises an important research question in light of the above discussion.

\subsection{Theoretical frame of reference}

In this section the study explains how it adopts two well-known theories to create a theoretical framework to address research question. In the first part we discuss transaction costs economics which is used as a proxy for the market perspective, followed by RBV which is used to understand the actions of individual firms. Adding service boundaries to these two theories enables this study to create an initial theoretical framework (Figure 1).

Transaction cost economics (TCE) takes as its starting point the contractual and relational governance issues between buyers and suppliers (Yang et al. 2012; Williamson 1985; Greenberg et al. 2008). TCE proposes that the governance of the basic unit of business, a transaction, will either be organised by a market, or by a firm (hierarchy), or a hybrid of the two. According to TCE theory 'all economic activity can be considered as some form of exchange of a good or service between two or more firms (Yu and Chen, 2013:1224). TCE is a theoretical approach predominantly applied to the strategic decision making informing an outsourcing decision (Leiblein 2003; Gilley and Rasheed 2000; Gilley et al. 2006); because at heart TCE tries to answer the question of where the boundary between a firm and the market should be. TCE argues that firms select the organisational structure with the lowest transaction cost that effectively safeguards against partner opportunism, ensures that partners fulfil 
contractual obligations, and provides a framework for dealing with uncertainties (Yang et al. 2012). In summary TCE focuses on the boundaries of the firm and the market which suggests alignment with this study's interest in service boundary dynamics.

\subsubsection{TCE and the market transactions of service providers}

Building upon the work of Ronald Coase (1937), transaction associated costs increase, when transactions are characterised by high asset specificity, uncertainty and frequency. The transaction cost approach views 'asset specificity' as the main determinant in conceptualising relationships in terms of choosing the optimal governance form (Williamson 1985). "Asset specificity refers to the level of customisation associated with the transaction" (McIvor 2009, p.47). The specification of assets that can also be referred to as the specific investment in a particular transaction (Williamson 1981) is an important characteristic in TCE, as it describes the value of utilising certain assets outside a transaction. Asset specificity attributes a loss of value when employing an asset in non-optimal uses, which results in quasi-rents (Williamson 1991; Vandaele et al. 2007). This quasi-rent approach assumes that the value of an asset or factor is higher in its best use than the value in its second-best use. Generally speaking, the higher the asset-specific investments, i.e. best use, the lower the value outside the transaction, i.e. second-best use, and vice versa. Every exchange in a market requires these kinds of transaction specific investments in order to gain quasi-rents (Klein et al. 1978), which occur in the form of physical customisation, human assets such as specialised knowledge or site specificity in terms of location. Empirical studies have tested the effect of asset specific investments on outsourcing or make-or-buy strategies with mixed results; Dutta et al. (1995) and Lee and Lim (2001), support a positive correlation between asset specificity and knowledge on the choice of governance form, McNaughton (2002) and Parmigiani (2007) deny a positive effect of asset specificity on outsourcing decisions.

Skjøett-Larsen, (2000) gives an example that combines both a customer led view of value (co)creation and investment in specific assets by the provider rather than a relational asset. He suggests that a service provider might invest in a medium specific asset (a dust free warehouse), gaining an advantage through asset ownership, of potentially being able to serve various clients requirements. While RBV concepts have mainly been applied to the exploitation of resources in a manufacturing or production environment, RBV can also be applied to services (Poppo and Zenger 1998; Wong and Karia 2010). In summary, the research utilizes TCE logic to evaluate the dynamics of service boundaries and later will adopt RBV logic to evaluate the core capabilities of service providers. This study also contributes to the literature through 
exploring the relational capabilities and relational and contractual of the less studied service provider side.

The role of TCE was explored through asking questions such as what services do you provide; what physical assets do you own; these TEC related questions are given in Table 2.

\subsubsection{RBV and the competitiveness of service providers}

As a theoretical lens RBV examines the exploitation of a firm's resources and capabilities as the antecedents for its competitive advantage (Penrose 1959, Wernerfelt 1984, Barney 1991). In contrast to Porter's (1985) competitive advantage theory, which focuses on externalities such as the level of barriers to new entrants in a market, RBV emphasises internal factors such as the firm's resources, capabilities and inter-relationships with competitors as the "primary sources of competitive advantage" (Liu et al. 2010, p.24). The central unit of analysis is the firm's strategic capability for exploiting tangible and intangible resources such as physical assets, human and organisational capital; (these could be for example data management resources

\begin{tabular}{|c|c|c|c|}
\hline & & & Theoretical frame of reference \\
\hline $\begin{array}{l}\text { TCE View } \\
\text { "Level of } \\
\text { integration" }\end{array}$ & $\begin{array}{c}\text { Frequent and } \\
\text { standardized market } \\
\text { transactions }\end{array}$ & $\begin{array}{l}\text { Transactions are } \\
\text { mainly governed } \\
\text { in a hybrid form }\end{array}$ & $\begin{array}{l}\text { Hierarchical structure } \\
\text { and highly specified } \\
\text { transactions }\end{array}$ \\
\hline \multicolumn{4}{|l|}{ RBV View } \\
\hline $\begin{array}{c}\text { "Level of } \\
\text { Capabilities" }\end{array}$ & $\begin{array}{l}\text { Strong focus on } \\
\text { physical assets }\end{array}$ & $\begin{array}{l}\text { Exploitation of relational } \\
\text { capabilities }\end{array}$ & $\begin{array}{l}\text { Exploitation of organizational } \\
\text { capabilities and knowledge }\end{array}$ \\
\hline \multirow[b]{2}{*}{$\begin{array}{c}\text { Industry View } \\
\text { "Level of service } \\
\text { provision“ }\end{array}$} & & \multicolumn{2}{|r|}{ Conceptual model } \\
\hline & $\begin{array}{l}\text { Standard outsourcing } \\
\text { activities }\end{array}$ & $\begin{array}{l}\text { Highly integrated } \\
\text { relationships }\end{array}$ & $\begin{array}{l}\text { Continuous adaptation of } \\
\text { systems }\end{array}$ \\
\hline
\end{tabular}

Figure 1. Ex-ante theoretical model

(DMR), IT-enabled planning resources and performance management resources (see Chae et al. 2014). Hence, viewing the firm as a bundle of resources, organisations are directed to focus on their core competencies (Prahalad and Hamel 1990). A recent extension of RBV has been ERBV OR ERBT an extended resource base view, which explicitly acknowledges inter organisational relationships as a key resource (Lewis et al. 2010). 
Two conceptual approaches dominate the explication and application of RBV theory. The first, is Barney's (1991) VRIO framework, which emphasises the full exploitation of a firm's resources. Second, is Teece et al.'s (1997) dynamic capabilities framework that includes "the firm's ability to integrate, build and reconfigure internal and external competences to address rapidly changing environments" (p.516). The development of RBV theory to understand the competitive advantage of a firm has emerged from a static view of resource attributes, to a more dynamic process that emphasises the ability to alter the resources in an efficient way rather than merely possessing them. The combination of service provider firms' capabilities, both tangible (e.g. logistics assets such as warehouses (including the dust free warehouse cited above from Skjøett-Larsen, (2000) and transportation related equipment they own) and intangible (e.g. specialised industry knowledge and know-how) suggests opportunities for highly differentiated service providers and service provision boundaries. Logistics operations usually involve capital-intensive asset investments, whereas attempts to foster supply chain wide solutions (i.e. horizontally and vertically integrated) requires a focus on collaborative measures and more intangible assets (Trentin 2011).

Figure 1 combines relevant RBV assumptions about resources and capabilities with TCE logic to create an ex-ante theoretical model. In Figure 1 RBV supports the development from assets to capabilities whilst TCE and the frequency and asset specificity of services in the market supports transaction costs growing in moving from standardised market dyads to hierarchical structures and customized services. The view from industry is added to support a dynamic from simple relationships/assets to ever more integrated and therefore complex relationships. This model then is in line with previous work, it summaries common assumptions but it does not offer explanatory analysis of how logistics provider firms move between segments, this will be supplied by the empirical fieldwork.

\section{Research methodology}

Academic work on exploratory issues such as the topic of this study suggests interviews as a means of data collection and an important source of evidence (Eisenhardt and Graebner 2007, Yin 2014). In order to guarantee critical insights, semi-structured interviews were conducted at senior management and CEO-level. Table 2 offers a representative sample of the interviewees and their job responsibilities. The research team developed a mix of open-ended and conceptual questions derived from the theoretical bases of RBV and TCE theory. Interview questions were asked in a sequential and consistent order, and whilst all the interviews adhered to a comprehensive interview guide, interview by interview scope was given for more open-ended 
questions. See Table 3 for questions from the TCE and RBV informed interview guide. In total, 30 interviews lasting between 45 to 90 minutes were conducted over a period of ten months in Germany. The use of a tape recorder was employed in most cases, insofar as it has been said to reduce researcher bias (Voss et al. 2002). Notably, three of the interviewees did not agree to be recorded, due to confidentiality issues.

Table 2: Description of interviewees (excerpt)

\begin{tabular}{|c|c|c|}
\hline ID & Role & Description of key responsibilities \\
\hline 3 & CEO & $\begin{array}{l}\text { The CEO of a small family-owned logistics carrier firm is mainly concerned } \\
\text { about keeping long-term customers to ensure the firm's turnover is stable. }\end{array}$ \\
\hline 6 & $\begin{array}{l}\text { Head of } \\
\text { Network } \\
\text { Development }\end{array}$ & $\begin{array}{l}\text { The management level responsibilities of interviewee } 6 \text { include the coordination } \\
\text { and organisation of strategic collaborations with other logistics partners within } \\
\text { central Europe in order to achieve larger scale and scope for the service } \\
\text { organisations' logistics offerings. }\end{array}$ \\
\hline 7 & $\begin{array}{l}\text { Key Account } \\
\text { Manager }\end{array}$ & $\begin{array}{l}\text { The key account manager for automotive customers develops and communicates } \\
\text { integrated and specialised logistics solutions with a focus on just in time and } \\
\text { express deliveries, the key objective is maintaining and extending customer } \\
\text { loyalty. }\end{array}$ \\
\hline 15 & CEO & $\begin{array}{l}\text { The CEO of a provider for bulk cargo and paper products represents the interface } \\
\text { between the administrative and operative logistics services offered to a single } \\
\text { customer. }\end{array}$ \\
\hline 14 & $\begin{array}{l}\text { Account } \\
\text { Coordinator }\end{array}$ & $\begin{array}{l}\text { The business developer for a large technology-oriented service firm coordinates } \\
\text { the communication and implementation of integrated and technology-driven } \\
\text { business solutions that currently help customers in the retail and high-tech } \\
\text { industry to increase supply chain visibility. The scale and scope of service } \\
\text { offerings is nearly unlimited and can be customised to any industry. }\end{array}$ \\
\hline
\end{tabular}

Coding schemes were developed throughout the data collection process, critically helping to fill any gaps and ensure there were no unanswered research questions. The data collection and data analysis interconnected and overlaps through an iterative process. The four iterative phases included (1) transcribing field notes, (2) coding and preparing qualitative data, (3) summarising and displaying findings and (4) drawing conclusions from analysis as it adheres to the initial conceptual framework. In summary, the research strategy started with a theory-driven development of an ex-ante theoretical framework (Figure 1). After collecting and analysing data, first conclusions in the form of service provider archetypes (see the conceptual 
model Figure 2) were drawn. Finally, a contextualised framework (Figure 3) illustrates the empirically derived findings within the logistics market.

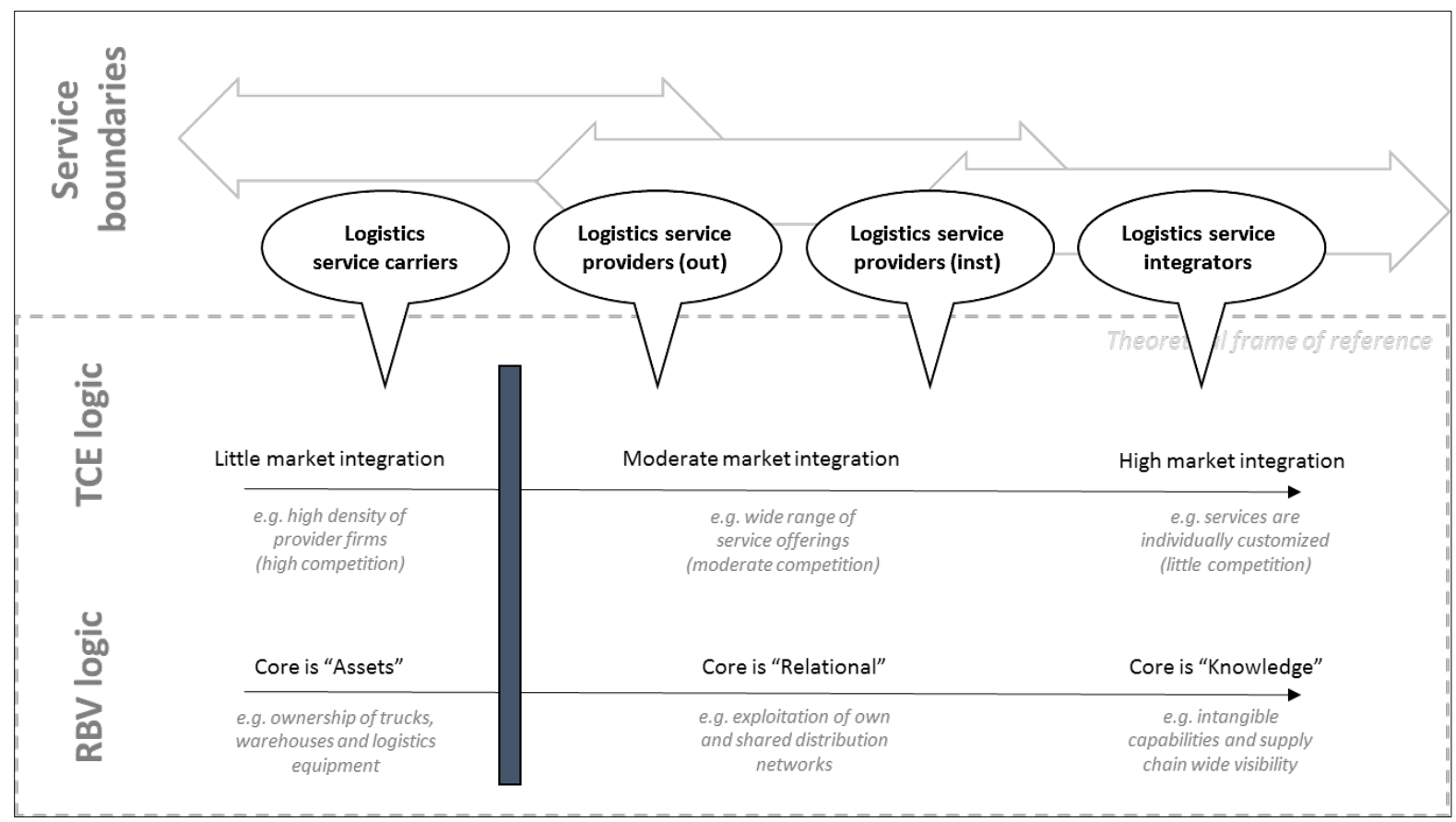

Figure 2. Conceptual model of service archetypes

Table 3: Interview guide showing theoretical links to TCE and RBV

Interview guide I: Questions informed by TCE.

- What is the frequency of certain/particular logistics transactions?

- How are these transactions governed?

- What is the time dimension for particular transactions, projects, contracts?

- What investments are necessary for certain transactions?

- To what extent are other suppliers available for certain transactions?

- What is the nature of transaction costs for certain activities?

- Which transactions have high or low transaction costs?

- To what degree can your organisation be replaced (from client view)?

○ How easily can you change your suppliers or subcontractors?

- How specific are transactions and assets tailored to your customers' needs?

- To what degree can future requirements be forecasted or anticipated?

$\circ \quad$... customer requirements?

○ ... technological requirements?

○ ... share of outsourced activities?

Interview guide II: Questions informed by RBV

Which (tangible) resources / assets are owned by your organisation?

- $\quad$ How do you access and exploit other (necessary) resources? 


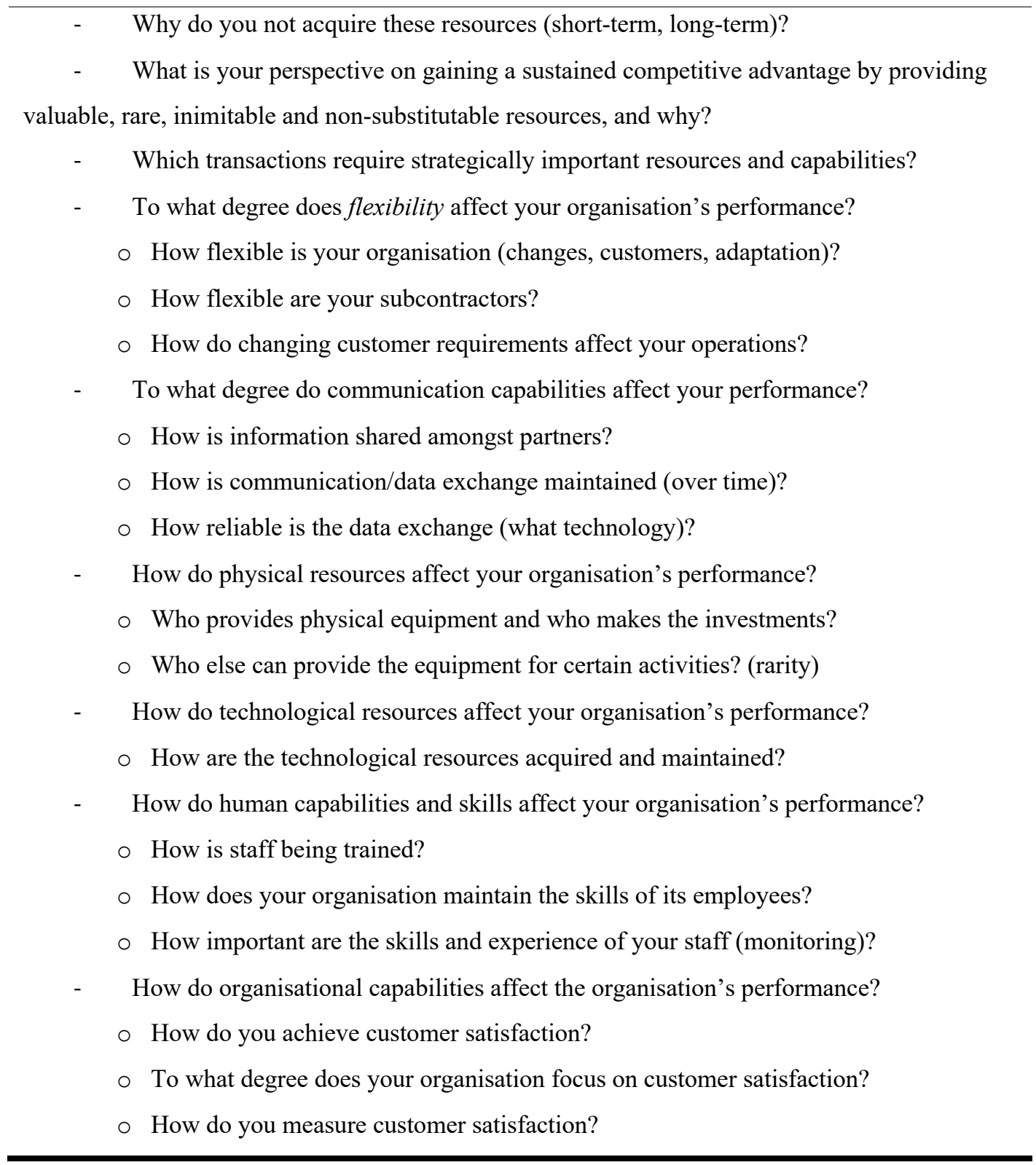

\section{Data analysis}

The data analysis articulated the ways provider firms position themselves in the market through developing service archetypes. It should be emphasized that these archetypes are different to previous categorisations of TPLs as these come solely from provider firms; outside of aiding our understanding of providers they are not intended as replacements for existing TPL definitions.

\subsection{Developing a narrative of service provision boundaries}

The analysis of empirical interview data is aligned to the ex-ante model and starts by exploring the core business of firms stretching from a purely asset-based offering to a relational and 
knowledge-based offering. Analysis also explored the transactional specifications and dynamics in the market.

\subsubsection{Standardized logistics activities: "There are large number of firms in Germany right now"}

The primary focus of most carrier firms within one of the most asset-driven markets within Europe (i.e. Germany) is to fully utilize logistics assets and equipment. For instance, most carrier firms own trucks or delivery vehicles (in the sample ranging from 10 to 100) as well as several warehousing facilities. However, in the logistics industry this utilization focus leads to the development of a heavily commoditized market, where service firms mainly use their own assets. "We make an effort to conduct most of our business with our own equipment. However, for bigger projects, such as a two-day transportation, we hire additional subcontractors. But we conduct $75 \%$ to $80 \%$ of the transports with our vehicle fleet" (Interviewee 11). These provider firms find themselves in a position, where they are not able to develop more relational capabilities in order to strengthen and foster close and long-term customer relationships. TCE theory supports this interpretation that highly standardised operations using low level technology and equipment is easy to duplicate and therefore, the logistics firms' customers can easily and at low cost switch between competitors.

There was a consensus among the interviewees that service firms in such commoditized markets are solely focused on organising their internal operations, i.e. increasing economies of scale. Interviewee 10 points out that "our sales department is very innovative in terms of consolidating shipments from different customers. For example, we transport steel components on top of flowers". Commodification of the service offering means little bargaining power for the carrier as contractor and a strong emphasis on physical resources for standard activities. This becomes evident amongst most of the interviewees. "Just recently, I talked to other logistics firms at an event, and generally, the perception amongst all of them is to ideally have an updated and rather new vehicle fleet" (Interviewee 3). Focused relentlessly on utilization, management and CEO-level executives work on the operational activities such as transportation planning. For example, Interviewee 3 reported that their CEO occasionally drives a truck or unloads trailers in the warehouse when staff resources are tight. But solutions do not lie in adding more of the same types of physical resources: "We are building a new warehouse this year [...] because we want to reduce our vehicle fleet by another 20 trucks" (Interviewee 29). Yet the same interviewee reported that additionally the organization would be extending their existing warehousing space; still focusing on physical assets rather than more relational and collaborative assets. "We typically do not have a contractual relationship [...] and it is mainly 
based on trust [...] and we experience that if you do a good job you can rely on your partners [...] and expect the same [orders] every day" (Interviewee 3).

\subsubsection{Larger scale and scope of services: "We can use the truck for something else, which means the planning becomes more adaptable”}

In line with the TCE theory, service providers that target more customized and specialised solutions benefit from this higher bargaining power and can better exploit their specific assets. The interviewees confirm that provider firms have established transportation networks, for instance, that are highly asset-specific including both own as well as collaborative facilities and vehicles. "[Our firm] has access to ... well, there are different models. We either use our partner's own vehicle fleet or we expand through additional subcontractors. Some partners exclusively use subcontractors. That means they do not have a single vehicle. [...] In addition, [our firm] possesses a pool of trailers, consisting of several thousand swap trailers which are used to deliver cargo within Germany every day" (Interviewee 12). It becomes apparent, however, that the focus of operations still lies on conventional and commoditized activities such as transportation and warehousing. "We exploit our contractors' capabilities and assets, such as vehicles and trailers, especially for regional deliveries to the final customers" (Interviewee 6). However, relational capabilities allow service providers to collaborate with other partners. "In various countries, such as South America or China and also in Eastern Europe, especially in Russia, we collaborate with selected partners [who we have worked with] over many years" (Interviewee 23).

What emerged from the interviews was that these more advanced types of provider usually developed from the more commoditised service carriers discussed above. Therefore, crossing the boundaries between different levels of service provision is achievable. Interviewee 7 related their firm's starting up as a small transportation carrier for local cheese manufacturers. "We started with a vehicle fleet of two or three cars, and today we have our own fleet of almost 100 vehicles [...], including normal transporters and 7 1/2 ton trucks [...], 7 1/2 ton trucks with hangers [...], but [we] also conduct conventional car deliveries, such as packages". The interview data strongly suggests that the core focus of service provision over time switches from purely asset-based to more relational-based services. Interviewees 6, 7 and 23, for instance, stress that their day-to-day activities involve maintaining close customer relationships in the form of communicating and aligning service offerings to the customer requirements, to ultimately offer a solution not a series of processes (Interviewee 23). 
In a logistics service context, this means that relational capabilities can be transformed to larger scale distribution and transportation networks that will result in understanding the customers' specific needs. "We are interested in identifying where the information flow starts. Does it start with the producers or at the end of the production line? [...] At the moment, it [the information flow] is not continuous; it is interrupted at several points, [since] several providers are in charge" (Interviewee 6). Interviewee 6 gives a representative example of how in services the inter-organisational relationships are evident today and still need to be improved on in the future. The importance of such close collaborations, however, also represents challenges within larger scale service networks. A representative example was highlighted by interviewee 29 , who collaborated very closely with a large-scale European service provider operating hundreds of carrier units and vehicles every day. Their partner firm "went out of business within 3 months and there was no prior sign for a stumbling business". This case was in the media and attracted the attention of the whole market. All in all, interviewees conclude that there is a need to further integrate both horizontally as well as vertically in order to truly become a market leader within the logistics industry.

\subsubsection{Customized and specified services: "We do not have many direct competitors because we are operating in a niche market"}

In line with the development of the 3PL industry in Europe during the 1980s and 1990s, service firms have further refined their capabilities and started to specialise in the niche markets. "Due to the corporate structure [sic] [hierarchical structure], our annual profit represents the annual cost savings for him [sic] [our customer]" (Interviewee 15). Such providers are basically institutionalised into a focal firm's hierarchical structure and therefore offer individuated services to a single customer across manufacturing, production, retail and consumer goods industries. "Our most important asset is the equipment [...] because it is specific to the products. [...] We cannot use it for shipments or material [handling] of any other company" (Interviewee 4). Provider firms are not limited to offering their services to any particular industry anymore, but can focus their operations on niche markets. Service provision, even though it is still commoditized, can be highly integrated into the customer's supply chain and operational processes, following a hierarchical governance structure. Here, provider firms are solely responsible for coordinating and managing the internal and external logistics and sourcing activities. "We are governed as an internal logistics firm [...] that operates and handles about 80 per cent of the [customer's] total volume per year" (Interviewee 15). 
The existence of the specialised and dedicated provider firms that organise and manage the entire logistics function for a single customer represents the boundaries of a more integrated but still standardised service firms. "We cover the sourcing function [...], which includes ... for example, we look at the Asian market for similar or benchmark products, and if we like one [and] we decide our customer needs that as well, we approach the suppliers directly and negotiate the price with them. Afterwards we approach our logistics department and undertake the steps for importing the products" (Interviewee 5). In this service provider context, the range of services offered is more than in standardised providers but more critically includes close supplier and customer interaction.

\subsubsection{A higher form of adaptive service solutions: "Our customers know that we can offer them all solutions along the supply chain"}

Given the trend towards internationalisation and the emphasis placed on global sourcing strategies, logistics operations have become increasingly complex and responsive. "We offer a complete solution [...] from the internet portal to the logistics functions [...], including financing and payment schemes" (Interviewee 13). Correspondingly, global supply chains, networks and systems have ultimately led to the emergence of systems sellers and systems integrators. Interviewee 13 also stresses that "we don't have our own assets or distribution networks. We subcontract everything to external service providers". Such integrator firms are responsible for integrating and coordinating supply chain wide operations that span beyond conventional transportation, distribution and order management services to include managing the supplier and customer interactions. "We developed a lot of know-how in integrating different systems into one system [...] and it requires a lot of know-how to run these systems without errors" (Interviewee 14).

The interviewees confirmed that the logistics industry is highly competitive and that long established provider firms constantly find new ways of positioning themselves within the market by aligning their service offerings to current customer requirements. Solution or integrator providers derive greater bargaining power from knowing what their customers' need; "We guarantee customer retention by being the only firm that can offer integrated solutions" (interviewee 14). Solution providers then, from their responses in the interviews, facilitate the continuous adaptation of systems- this is knowledge based activity involving higher capabilities than physical asset or relationship management (see Figure 3). This is the service provision boundary that offers more attractive profit margins and less intense competition. "We operate in a market where there are not thousands of [...] competitors, as it is the case for conventional transportation services. [...] We are more specialized [and our services] are associated with 
high investment [costs]." (Interviewee 14). With regard to the ownership of assets, solution provider firms place little emphasis on a strict distinction between market and hybrid governance. Instead, the delegation of agency and the capabilities related to customer interaction attract most consideration. "We are entirely responsible [...] for our customers' operations [...] and the carriers and suppliers communicate with us directly. [...] We operate in the name of our customers" (Interviewee 14).

Some participants point out that they aim to achieve supply chain wide solutions, but are highly dependent on their relational capabilities in order to offer commoditized service activities that are of a more operational nature. Paradoxically then, operational tasks are still a crucial asset of even full solution provider firms, for example interviewee 9 who refers to his organization as integrators. "We undertake both procurement [...] and distribution logistics [...] starting from the production of the product, [...] delivery of the [raw materials], [...] consolidate and tailor the products [...] and the final distribution to the retail stores" (Interviewee 9). Theoretically, integrators should implement a strict hierarchical structure within and across multiple supply chains simultaneously that would allow them to coordinate efficiently. In practice, this hierarchical structure is nearly impossible to achieve, given that the most responsive and integrated levels of service provision involve an inordinate amount of operational tasks and therefore the integrator acts as an agent themselves.

\subsection{Dynamic service boundaries and logistics service provider archetypes}

The above narrative of the empirical interview data set in a competitive market ultimately results in the proposition of the following four service archetypes that are further illustrated in the conceptual model (Figure 2). The proposition of the four archetypes is aligned to the exante model (Figure 1) and focuses on the service boundaries within the logistics market in Germany:

1. Logistics service carriers (LSC): Provider firms possess privately owned assets in order to conduct standardised logistics services. There is no or little market integration (in the form of vertical integration) or interaction with the end-consumers. The boundaries are typically represented by asset-based core functions.

2. Outsourcing logistic service providers (LSP out): Service providers partly own physical assets or logistics equipment, but firms can rely and exploit their relational capabilities in order to maintain a national or even European-wide logistics networks. These provider firms focus on a continuous communication with multiple upstream suppliers and manufacturers 
even though they have limited interactions with downstream customers or end-consumers. LSP out service offerings are on a large scale but smaller in scope.

3. Institutional logistics service providers (LSP inst): Assets are partly owned by the provider firms but primarily shared with one major customer; the provider firms manage and organise all information flows between the single customer and its sub-tier suppliers (upstream) and sometimes even to downstream end-consumers.

4. Logistics service integrators (LSI): Physical assets support the facilitation of integrated solutions. LSI firms place emphasis on the continuous adaptation with (downstream) customers and/or end-consumers. LSI primarily rely on their organisational capabilities and they delegate agency across the supply chain with multiple customers in a hierarchical governance form.

Table 4 below offers a summary of excerpts from individual interviews linked to the interviewees of table 2 above linked to at least one of the four archetypes.

Table 4. Case Firms' Characteristics (Excerpt - to match with interviewees table 3.1)

\begin{tabular}{lll}
\hline Firm & Logistics Service Provision Characteristics & Fixed Assets / or (if \\
No. & available)
\end{tabular}

Revenue in EUR p.a.

Case Firms' Characteristics for LSC Service Provision

3 Transportation and storage of general cargo; mainly full truck loads; partially subcontracted to carriers.

Customer base consists of manufacturers and producers in the FMCG industry.
60 privately owned $\mathrm{HGVs}$; local warehouse for palletised and chilled products; one national branch.

Annual Revenue $7.5 \mathrm{mn}$.

Case Firms' Characteristics for LSP (out) Service Provision

6 General cargo and perishable goods, FTL and mostly LTL shipments, consolidated transportation services include pick up, transshipment and delivery.

Customer base in FMCG industry, mainly retailer and wholesaler.

7 CEP services; global distribution network includes pick-up, delivery and handling of small shipments.

Customers in the B2B as well as in the B2C market; focus on small and urgent deliveries.
Few owned trucks; $>10,000$

transportation units; $>10,000$

employees; >400 global

offices.

Annual Revenue 4.4 bn.

100 privately owned vehicles;

15 national offices; five

European offices.

Annual Revenue 140.0 mn. 


\begin{tabular}{lll}
\hline & Case Firms' Characteristics for LSP (inst) Service Provision & \\
& Supply chain wide solutions, including replenishment and \\
delivery of bulk cargo in FTL shipments on a national scope. & Two warehouse facilities; 180 \\
Customer is a German groceries retailer. & employees. \\
& Annual Revenue N/A. \\
\hline Case Firms' Characteristics LSI Service Provision & \\
Full supply chain coordination and provision of B2C and B2B & 110 global offices in 60 \\
solutions, includes operating and managing online shops, & countries; operating (not \\
customer service, and IT implementation. & owning) >200 logistics \\
Customer base in fashion and high-tech industries. & facilities. \\
\end{tabular}

Table 5 summarises the conclusions that are drawn from the analysis of the interviews, including the challenges that service provider firms face in the competitive markets.

Table 5. Characteristics of service archetypes

\begin{tabular}{|c|c|c|c|c|c|}
\hline $\begin{array}{l}\text { Service } \\
\text { archetypes }\end{array}$ & Scale & Scope & $\begin{array}{l}\text { Profitability } \\
\text { drivers and } \\
\text { business focus }\end{array}$ & $\begin{array}{l}\text { Assets and } \\
\text { capabilities }\end{array}$ & $\begin{array}{l}\text { Boundary } \\
\text { challenges }\end{array}$ \\
\hline $\begin{array}{l}\text { Service } \\
\text { Carriers }\end{array}$ & $\begin{array}{l}\text { Domestic or } \\
\text { local } \\
\text { customers }\end{array}$ & $\begin{array}{l}\text { Basic } \\
\text { transactions } \\
\text { such as } \\
\text { transportation } \\
\text { and } \\
\text { warehousing } \\
\text { operations }\end{array}$ & $\begin{array}{l}\text { Very low profit } \\
\text { margins due to high } \\
\text { percentage share of } \\
\text { labour and variable } \\
\text { costs }\end{array}$ & $\begin{array}{l}\text { Physical assets, } \\
\text { mostly } \\
\text { commoditized and } \\
\text { sometimes } \\
\text { uniquely } \\
\text { customized }\end{array}$ & $\begin{array}{l}\text { Industry-driven } \\
\text { fragmentation of } \\
\text { the market } \\
\text { impacts } \\
\text { competitive } \\
\text { success }\end{array}$ \\
\hline $\begin{array}{l}\text { Service } \\
\text { Provider } \\
\text { (out) }\end{array}$ & $\begin{array}{l}\text { Large } \\
\text { customer } \\
\text { base on a } \\
\text { domestic } \\
\text { and } \\
\text { European } \\
\text { level }\end{array}$ & $\begin{array}{l}\text { Multiple } \\
\text { logistics } \\
\text { solutions } \\
\text { ranging from } \\
\text { simple } \\
\text { warehousing } \\
\text { and distribution } \\
\text { to integrated } \\
\text { network } \\
\text { planning }\end{array}$ & $\begin{array}{l}\text { Economies of scale } \\
\text { reduce the costs per } \\
\text { service; however, } \\
\text { individual profit } \\
\text { margins are still } \\
\text { low and } \\
\text { competitive }\end{array}$ & $\begin{array}{l}\text { Advanced } \\
\text { network } \\
\text { capabilities } \\
\text { through } \\
\text { standardised } \\
\text { organisational and } \\
\text { relational } \\
\text { structures (e.g. } \\
\text { horizontal } \\
\text { collaboration) }\end{array}$ & $\begin{array}{l}\text { Well-developed } \\
\text { network } \\
\text { structures hinder } \\
\text { individual and } \\
\text { customized } \\
\text { service solutions }\end{array}$ \\
\hline $\begin{array}{l}\text { Service } \\
\text { Provider } \\
\text { (inst) }\end{array}$ & $\begin{array}{l}\text { One single } \\
\text { domestic } \\
\text { customer }\end{array}$ & $\begin{array}{l}\text { Basic logistics } \\
\text { activities across } \\
\text { all supply chain }\end{array}$ & $\begin{array}{l}\text { Fully customized } \\
\text { solutions increase } \\
\text { the bargaining }\end{array}$ & $\begin{array}{l}\text { Strong relational } \\
\text { capabilities and } \\
\text { industry }\end{array}$ & $\begin{array}{l}\text { Small customer } \\
\text { base limits the } \\
\text { service offerings }\end{array}$ \\
\hline
\end{tabular}




\begin{tabular}{|c|c|c|c|c|c|}
\hline & & $\begin{array}{l}\text { levels starting } \\
\text { from supplier } \\
\text { pick up to } \\
\text { consumer } \\
\text { delivery }\end{array}$ & $\begin{array}{l}\text { power and therefore } \\
\text { justify higher } \\
\text { prices; however, no } \\
\text { economies of scale } \\
\text { possible }\end{array}$ & $\begin{array}{l}\text { knowledge; uses } \\
\text { clients' equipment }\end{array}$ & $\begin{array}{l}\text { and competitive } \\
\text { success }\end{array}$ \\
\hline $\begin{array}{l}\text { Service } \\
\text { Integrator }\end{array}$ & $\begin{array}{l}\text { Multiple } \\
\text { global and } \\
\text { multi- } \\
\text { national } \\
\text { customers }\end{array}$ & $\begin{array}{l}\text { Supply chain } \\
\text { wide operations } \\
\text { integrated and } \\
\text { enhanced } \\
\text { through } \\
\text { technological }\end{array}$ & $\begin{array}{l}\text { High degree of } \\
\text { scalability of } \\
\text { developed solutions } \\
\text { leads to highly } \\
\text { profitable business } \\
\text { units }\end{array}$ & $\begin{array}{l}\text { Global reach and } \\
\text { integrated } \\
\text { network } \\
\text { capabilities } \\
\text { through integrated } \\
\text { IT systems and } \\
\text { capabilities }\end{array}$ & $\begin{array}{l}\text { Multi-national } \\
\text { and cross- } \\
\text { industry service } \\
\text { supply chain } \\
\text { solutions are } \\
\text { holistic but } \\
\text { indeterminate in } \\
\text { terms of core } \\
\text { assets }\end{array}$ \\
\hline
\end{tabular}

\section{Discussion}

This study broke with convention and explicitly studied the provider perspective on growth and movement across market segments. Predictions from TCE theory that the market would be used where the logistics services provided were basic, commoditised, and low technology were confirmed. LSCs competing in these markets invest in assets to raise utilisation - at the expense of addressing inter organisational relationships; captured succinctly in the comment that these firms favour new fleet above all else. Again in line with TCE, where the customer required a more customised and specialised logistics service, providers could offer more integration and earn higher margins.

The RBV logic of exploiting assets and focusing on the core business operations was also confirmed, as illustrated in the bottom part of the conceptual model. Data shows that owning and exploiting resources is not enough to gain competitive success, it is rather the development of relational and organisational capabilities that lead to increasing options for commercial success.

The interview data both suggests that more advanced LSPs have come through from the commoditised market segment and that they have achieved this move through offering more relational (not asset) based services. Firstly, the interviews demonstrated that acquiring physical assets might increase competitiveness within LSC firms, but it does not contribute to developing integrated and profitable service [solution] offerings. Secondly, LSP (out) and LSP (inst) firms mostly rely on their relational capabilities and avoid acquiring asset-based services. 
Thirdly, LSI firms attempt to maintain and increase their intangible resources, such as knowledge and industry know-how, to achieve offering the highest form of integrated and supply chain wide service solutions. Whilst RBV has been helpful the emphasis upon the value of relationships suggests that extending RBV to include organisational relationships (ERBV) would offer greater analytical traction than RBV alone.

What is most surprising perhaps is that through examining the provider perspective, this study has been able to identify that these different market overlap. The data suggests that boundary crossing is not just a linear process but includes switching back and forth between physical, transactional, relational and knowledge based as well as customized and adaptive services. Hence, the data suggests that the distinctions between service providers are dynamic not fixed, and therefore offer potential for movement between categories. Hence in Figure 3 overlap between LSCs and LSPs is shown, and the degree of essential contact between LSI's and LSCs is shown by a line.

Utilising the insights generated through the identification of archetypes of service provision (shown as industry provision, reflecting its origins in the interviews with industry), a model representing a dynamic approach to service boundaries is developed as shown in Figure 3. The level of solution integration and the core capabilities focus are two dimensions in the figure which help to define the boundaries between service provider types. The core capabilities within a service market range from asset-based to relational-based to knowledge-based. The level of integration at the interface is found to range from standardized to integrated to adaptive solution services. Figure 3 juxtaposes the polar extremes of LSC services (left) and LSI services (right). However, the research is not focused on identifying innate differences between service provider extremes, in fact quite the opposite. In short, even though there are the proposed archetypes of service provision, this classification only relates to the boundaries between service provision models. In contrast to putting provider firms into 'boxes' the model stresses the dynamics and overlap between these service archetypes. However, the data suggests that offering such integrated services can only be accomplished by switching back and forth between physical assets (e.g. network structures) and supply chain wide coordination (e.g. online platforms). Such switching takes place on a daily basis, when service firms for instance take charge of coordinating their sub-tier carriers' asset and equipment network into the final customers' ERP system. This coordination ultimately results in offering integrated solutions that are based on physical resources. 


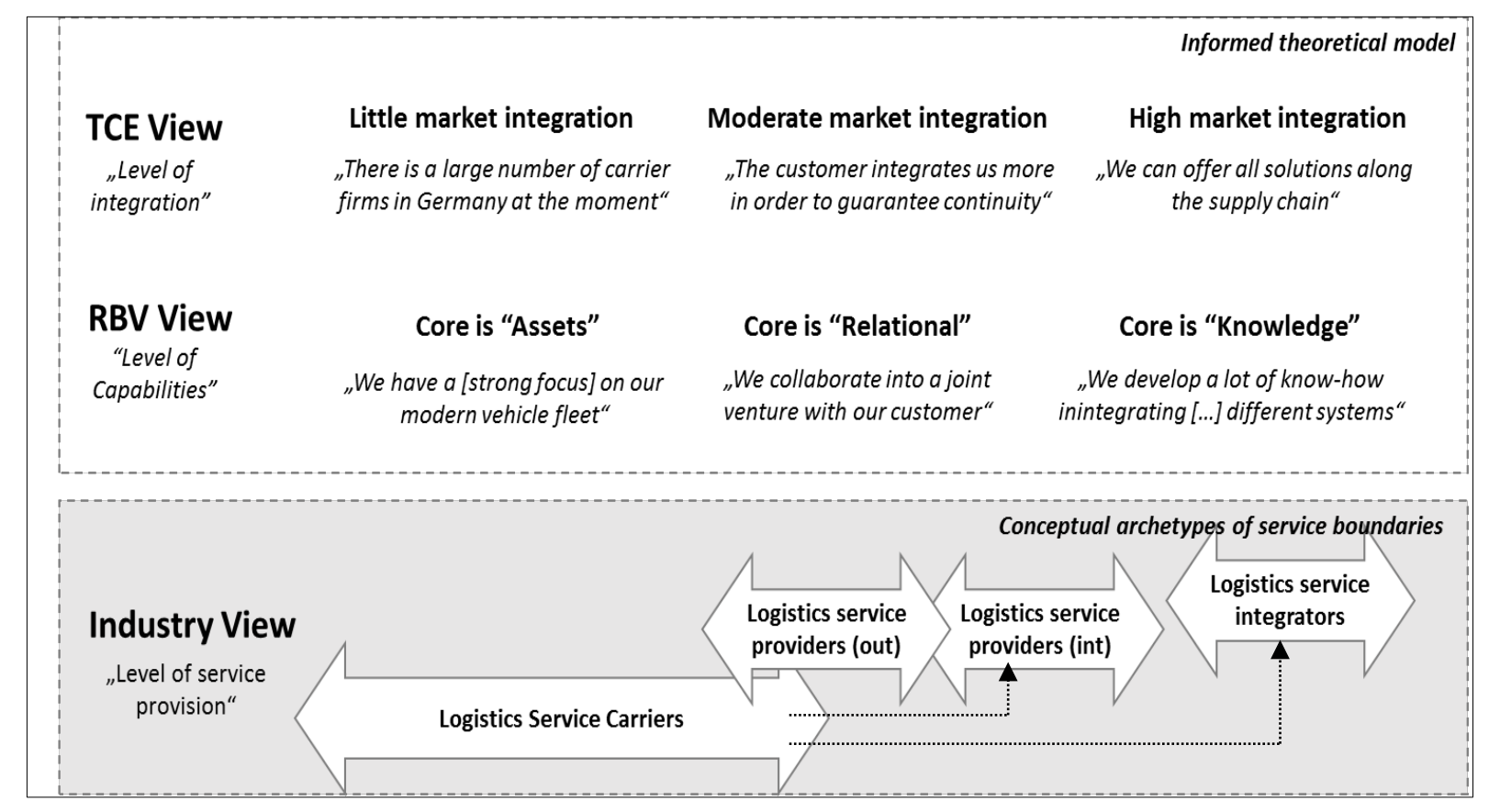

Figure 3. Four archetypes of service provision boundaries

With regard to common definitions of integrator or solutions providers (who by definition are not supposed to own any assets), Figure 3 highlights that in particular the LSI archetype is characterised by boundary crossings back and forth in order to access and exploit capabilities and knowledge from other archetypes. So the data suggests that even the highest form of integration strongly relies on access to physical and tangible assets and resources. The interviewees confirmed that for example, in order to establish supply chain wide transparency and visibility over time, it is necessary to access physical asset based service providers' physical distribution and transportation networks. Hence, these empirical findings from a provider perspective, do not support the existence of a pure and abstract solution or integrator role. That is from extant literature one would anticipate that 4PL solution providers' eliminate all ties to owning physical assets and resources; this data contradicts that common view of 4PLs.

In terms of our research question - How can service provider firms in competitive industries re-position their offerings? The dilemma commoditised carrier firms face is being 'trapped' in a low margin market position, provoking attempts to cross boundaries. From the interviews, these commodity carrier firms frequently aim to extend their service offerings by acquiring assets (e.g. warehouses or a vehicle fleet). However again and again it is evident from interviewees, that operational transactions based on commoditised assets do not involve relational and adaptive capabilities and remain very labour and capital intensive. Hence, just acquiring more assets does not guarantee a more profitable market position or relate to 
competitive success. It is rather the further development of relational and knowledge capabilities that enables firms to move up towards more integrated services and high-margin market segments.

Additionally, constant contact (and therefore the potential for movement) was identified between categories. For example, boundary crossings in particular take place amongst highly integrated services (right in Figure 3) and commoditised and asset-based services (left in Figure 3). LSI services are the most integrative and adaptive supply chain solution providers but they actually still gain knowledge and capabilities from (commoditised) network players that have acquired large scale logistics businesses over time.

\section{Conclusions and implications}

The study examined service providers in the context of the highly competitive German market for logistics. Empirical data collected from participating senior management and CEO-level participants informed the analysis on how firms within such highly competitive markets can reposition themselves. For commoditised carriers it is critical to gain more relational and knowledge-based capabilities from forming alliances and collaborations (horizontally). Purchasing more physical assets will not lead to less commoditised, higher added margin work. Intriguingly the study suggests well-established solution provider firms that already possess the necessary relational and adaptive capabilities depend on accessing more asset-based service providers to maintain their performance over time.

Whilst extant research has used RBV and TCE theory, it has previously taken a customer or outsourcing perspective. This study has reminded us that services can also be seen as a commodity, in particular the highly asset-based logistics carriers that are 'trapped' within a commoditised service market. Four service provision archetypes were identified but more importantly overlap was seen between asset based and relational and knowledge based providers.

\subsection{Managerial implications}

The finding that LSPs and critically LSIs still depend on access to physical resources both explains why a pathway to higher margin, integrated, relational services remains open and confirms the competitiveness of the market. For policy makers the overlaps identified between providers suggest such diversity is necessary for a healthy market in [logistics] service provision. It could be that practitioners are innately aware that the perhaps overly stylised 
categorisations that emerge from customer led perspectives may exaggerate differences at the expense of commonalities? Certainly key to the success of logistics integrators seems to be the quality of their access to the likes of LSCs who perform basic, but vital functions. This it is suggested, is an unusual perspective on what is seen as a rarefied and rather exalted form of logistics service provision.

\subsection{Limitations and future research}

With regard to generalisability this study has addressed a highly competitive - and German service market and its findings may not apply to less competitive [and less European?] service markets. Qualitative data collection has its critics, to address such concerns an iterative analysis method was adopted that constantly switched between data, analysis and findings.

In order to improve and build upon this study, this research has been among the first to identify the value of an extended RBV view on logistics service provision. Antecedents for ERBV are there for example in Skjøett-Larsen's (2000) use of TCE and network theory where network thoery was used to draw upon the IMP's interest in interaction in a very similar use to ERBV. A theorectical approach that saw relationships as key resources would be valuable in exploring the intercomnnection of categories and overlap identified in this study. As stated this study is limited to the provider perspective, arguably a study that set out to give equal weight to both customer and provider perspectives would have greater generalisability.

\section{Acknowledgement}

Authors would like to thank two anonymous reviewers for their encouraging and constructive comments for improving the overall quality of the manuscript.

\section{REFERENCES}

Bagchi, P. K. and Virum, H. (1996). "European logistics alliances: a management model." International Journal of Logistics Management 7(1): 93-108.

Barney, J. B. (1991). "Firm Resources and Sustained Competitive Advantage." Journal of Management, 17(1): 99-120.

Barney, J. B. (2001). "Is the resource-based "View" a useful perspective for strategic management research? Yes." Academy of Management Review 26(1): 41-56.

Bask, A. H. (2001). "Relationships among TPL providers and members of supply chains - A strategic perspective." Journal of Business \& Industrial Marketing 16(6): 470-486.

Berglund, M., Laarhoven, P. V., Sharman, G. and Wandel, S. (1999). "Third-Party Logistics: Is There a Future?" International Journal of Logistics Management 10(1): 59-70.

Bowersox, D. J., Closs, D. and Cooper, B. (2012). Supply Chain Logistics Management, 4th ed., McGraw-Hill Education.

Bustinza, O. F., Bigdeli, A. Z., Baines, T. and Elliot, C. (2015). "Servitization and Competitive Advantage: The Importance of Organizational Structure and Value Chain Position." ResearchTechnology Management 58(5): pp. 53-60. 
Chae, B (K)., Olson, D. and Sheu, C. (2014). "The impact of supply chain analytics on operational performance: a resource-based view." International Journal of Production Research 52(16): 46954710.

Chen, J. and Chen, B. (2016). "Competing with customer returns policies." International Journal of Production Research 54(7): 2093-2107

Chiu, M-C., Chu, C-Y. and Chen, C-C. (2018). "An integrated product service system modelling methodology with a case study of clothing industry." International Journal of Production Research 56(6): 2388-2409

Chu, Z. and Wang, Q. (2012). "Drivers of Relationship Quality in Logistics Outsourcing in China." Journal of Supply Chain Management 48(3): 78-96.

Cieslik, A. and Michalek, J. (2015). Liberalization of Transportation Services in the EU: the Polish Perspective, $6^{\text {th }}$ ed., Oxford.

Coyle, J. J., Bardi, E. J. and Langley, C. J. (2003). The Management of Business Logistics: A Supply Chain Perspective, 7th ed., South-Western Thomson Learning.

Cui, L. and Hertz, S. (2011). "Networks and capabilities as characteristics of logistics firms." Industrial Marketing Management, 40(6): 1004-1011

Dutta, S., Bergen, M., Heide, J. B. and John, G. (1995). "Understanding Dual Distribution: The Case of Reps and House Accounts." Journal of Law, Economics, and Organization 11(1):189-204.

Ellram, L. M. and Cooper, M. C. (1990). "Supply chain management, partnership, and the shipper-third party relationship" International Journal of Logistics Management 1(2): 1-10.

Eisenhardt, K. M. and Graebner, M. E. (2007). "Theory Building from Cases: Opportunities and Challenges." Academy of Management Journal 50(1): 25-32.

Fabbe-Costes, N., Jahre, M. and Roussat, C. (2008). "Supply chain integration: the role of logistics service providers." International Journal of Productivity and Performance Management 58(1): 7191.

Faber, N., René, B.M., Koster, D, and Smidts, A. (2018). "Survival of the fittest: the impact of fit between warehouse management structure and warehouse context on warehouse performance." International Journal of Production Research 56(1-2): 120-139.

Gilley, K. M. and Rasheed, A. (2000). "Making More by Doing Less: An Analysis of Outsourcing and its Effects on Firm Performance." Journal of Management 26(4): 763-790.

Gilley, K. M., Rasheed, A. A. and Al-Shammari, H. (2006). Research on Outsourcing: Theoretical Perspecitves and Empirical Evidence. In Barrar, P. and Gervais, R., Eds., Global Outsourcing Strategies: an international reference on effective outsourcing relationships, Hampshire: Gower, 1732.

Greenberg, P. S., Greenberg, R. H. and Antonucci, Y. L. (2008). "The role of trust in the governance of business process outsourcing relationships: A transaction cost economics approach." Business Process Management Journal 14(5): 593-608.

Halldórsson, Á. and Skjøett-Larsen, T. (2004). "Developing logistics competencies through third party logistics relationships." International Journal of Operations \& Production Management, 24(2): 192206.

Hertz, S. and Alfredsson, M. (2003). "Strategic development of third party logistics providers." Industrial Marketing Management 32(2): 139-149.

Huemer, L. (2012). "Unchained from the chain: Supply management from a logistics service provider perspective." Journal of Business Research 65(2): 258-264.

Kayakutlu, G. and Buyukozkan, G. (2011). "Assessing performance factors for a 3PL in a value chain." International Journal of Production Economics 131(2): 441-452.

Klein, B., Crawford, R. G. and Alchian, A. A. (1978). "Vertical Integration, Appropriable Rents, and the Competitive Contracting Process." Journal of Law and Economics 21(2): 297-326. 
Kille, C. and Schwemmer, M. (2015). Top 100 in European Transport and Logistics Services 2013/2014, Nuremberg: Fraunhofer SCS.

Kowalkowski, C., Gebauer, H. and Oliva, R. (2017). "Service growth in product firms: Past, present, and future." Industrial Marketing Management 60: 82-88.

Langley, J. and Capgemini (2015). 2015 Third-Party Logistics Study - Annual Study on the State of Logistics Outsourcing. Results and Findings of the 19th Annual Study.

Lahy, A., Li, Q., Found, P., Panalpina S, Wilson, M. and Ayiomamitou, N. (2017). "Developing a product-service system through a productisation strategy: a case from the 3PL industry." International Journal of Production Research 56(6): 2233-2249.

Lee, K. S. and Lim, W. S. (2001). A Game-theoretic perspective on transaction cost and the decision to make, buy or make-and-buy, unpublished.

Leiblein, M. J. (2003). "The choice of organizational governance form and performance: Predictions from transaction cost, resource-based, and real options theories." Journal of management 29(6): 937961.

Lewis, M., Brandon-Jones, A., Slack, N., Howard, M. (2010). "Competing through operations and supply: The role of classic and extended resource-based advantage." International Journal of Operations and Production Management 30(10): 1032-1058

Lieb, R. C. (1992). "The use of third-party logistics services by large American manufacturers." Journal of Business Logistics 13(2): 29.

Mantin, B., Krishnan, H. and Dhar, T. (2014). "The Strategic Role of Third-Party Marketplaces in Retailing." Production and Operations Management 23(11): 1937-1949.

Marasco, A. (2008). "Third-party logistics: A literature review." International Journal of Production Economics 113(1):127-147.

McIvor, R. (2009). "How the transaction cost and resource-based theories of the firm inform outsourcing evaluation." Journal of Operations Management 27(1): 45-63.

McNaughton, R. B. (2002). "The use of multiple export channels by small knowledge-intensive firms." International Marketing Review 19(2): 190-203.

Murphy, P. R. and Poist, R. F. (1998). "Third-party logistics usage: an assessment of propositions based on previous research." Transportation Journal 37(4): 26-35.

Nilsson, E.A. (2017). Highly Competitive Industries and the Supply Curve. In Capitalism Power, Profits, and Human Flourishing. https://economics.csusb.edu/facultystaff/nilsson/personal/Capitalism\%20Text/00Title\%20Page.pdf Accessed 29/6/2018.

Parmigiani, A. (2007). "Why Do Firms Both Make and Buy? An Investigation of Concurrent Sourcing." Strategic Management Journal 28(3): 285-311.

Patton, M. Q. (2002). Qualitative Research \& Evaluation Methods, SAGE Publications.

Penrose, E. T. (1959). The Theory of the Growth of the Firm, New York: Oxford University Press.

Peters, T., Meijboom, R, and de Vries, E. (2018). "Interfaces in service modularity: a scoping review." International Journal of Production Research Open acess:1-16.

Prior, D. D. (2016). "Boundary spanning and customer service styles in business solutions implementation." Industrial Marketing Management 56: 120-129.

Poppo, L. and Zenger, T. (1998). "Testing Altermative Theories of the Firm: Transaction Cost, Knowledge-Based, and Measurement Explanations for Make-or-Buy Decisions in Information Services." Strategic Management Journal 19(9): 853-877.

Prahalad, C. K. and Hamel, G. (1990). "The Core Competence of the Corporation." Harvard Business Review 68(3): 79-91.

Quinn, J. B. and Hilmer, F. G. (1994). "Strategic outsourcing." Sloan management review 35(4): 43.

Roehrich, J. K. and Caldwell, N. D. (2012). "Delivering integrated solutions in the public sector: The unbundling paradox." Industrial Marketing Management, 41(6): 995-1007. 
Schoenherr, T. (2010). "Outsourcing decisions in global supply chains: an exploratory multi-country survey." International Journal of Production Research 48(2): 343-378

Sheffi, Y. (1990). "Third party logistics: Present and future prospects." Journal of Business Logistics 11(2): 27-39.

Shi, Y., Zhang, A., Arthanari, T. and Liu, Y. (2016). "Third-party purchase: an empirical study of Chinese third-party logistics users." International Journal of Operations \& Production Management 171(2): 189-200

Skjøett-Larsen, T. (2000). "Third party logistics - from an interorganizational point of view." International Journal of Physical Distribution \& Logistics Management 30(2):112-127.

Storbacka, K. (2011). “A solution business model: Capabilities and management practices for integrated solutions." Industrial Marketing Management 40(5): 699-711.

Teece, D. J., Pisano, G. and Shuen, A. (1997). "Dynamic Capabilities and Strategic Management." Strategic Management Journal 18(7): 509-533.

Trentin, A. (2011). "Third-party logistics providers offering form postponement services: value propositions and organisational approaches." International Journal of Production Research 49(6): $1685-1712$.

Van Hoek, R. I. and Chong, I. (2001). "Epilogue: UPS Logistics-practical approaches to the e-supply chain." International Journal of Physical Distribution \& Logistics Management 31(6): 463-468.

Vandaele, D., Rangarajan, D., Gemmel, P. and Lievens, A. (2007). "How to govern business services exchanges: Contractual and relational issues." International Journal of Management Reviews 9(3): 237-258.

Voss, C., Tsikriktsis, N. and Frohlich, M. (2002). "Case research in operations management." International Journal of Operations \& Production Management 22(2): 195-219.

Wernerfelt, B. (1984). “A resource-based view of the firm.” Strategic Management Journal 5(2): 171180.

Williamson, O. E. (1981). "The economics of organization: the transaction cost approach." The American Journal of Sociology 87(3): 548-577.

Williamson, O. E. (1985). The economic institutions of capitalism: firms, markets, relational contracting New York, London: Free Press.

Williamson, O. E. (1991). "Comparative economic organization: The analysis of discrete structural alternatives.” Administrative Science Quarterly 269-296.

Win, A. (2008). "The value a 4PL provider can contribute to an organisation." International Journal of Physical Distribution \& Logistics Management 38(9): 674-684.

Wong, C. Y. and Karia, N. (2010). "Explaining the competitive advantage of logistics service providers: A resource-based view approach.” International Journal of Production Economics 128(1): 51-67.

Yang, C., Wacker, J.G, and Sheu, C. (2012). "What makes outsourcing effective? A transaction-cost economics analysis." International Journal of Production Research 50(16): 4462-4476.

Yeung, K., Zhou, H., Yeung, A.C. and Cheng, T.C.E. (2012). "The impact of third-party logistics providers' capabilities on exporters' performance." International Journal of Production Economics 135(2): 741-753.

Yin, K. (2014). Case study research: Design and methods, 5th edition, London: SAGE Publishing.

$\mathrm{Yu}, \mathrm{S}-\mathrm{H}$, and Chen, $\mathrm{M}-\mathrm{Y}$ (2013). "Performance impacts of interorganizational cooperation: a transaction cost perspective." The Service Industries Journal 33(13-14): 1223-1241.

Zhang, M., Pratap, S., Huang, Q, and Zhao, Z. (2017). "Optimal collaborative transportation service trading in B2B e-commerce logistics." International Journal of Production Research 55(18): 54855501 . 